\title{
Motivational Strategies of Retail Company during Work from Home
}

\author{
Maribeth Padura ${ }^{1}$, Manuel Hernandez ${ }^{1}, \&$ Dr. Nickie Boy Manalo ${ }^{2}$ \\ ${ }^{1}$ College of Accountancy, Business, Economics and International Hospitality Management, Batangas State \\ University, Philippines \\ ${ }^{2}$ College of Accountancy, Business, Economics and International Hospitality Management, Graduate School \\ Faculty, Batangas State University, Philippines \\ Correspondence: Maribeth Padura, College of Accountancy, Business, Economics and International Hospitality \\ Management, Batangas State University, Philippines.
}

Received: December 1, 2021

Accepted: December 21, $2021 \quad$ Online Published: December 23, 2021

doi:10.5539/ibr.v15n1p98

URL: https://doi.org/10.5539/ibr.v15n1p98

\begin{abstract}
According to the management scholars Richard Kreitchner and Carlene Cassidy, "the term motivation, refers to a physiological process that gives behavior purpose and direction". It is thought that if an employee is motivated, they will be usually content with his employment, and since they will be happy, they will be able to provide their best effort and contribution to the task at hand. However, there are numerous sorts of motivation for everyone, and it is unlikely that every individual in the firm or in that particular area will be motivated in the same way. Employee Motivation Is defined as the Power That Propels Employees toward Achieving the Organization's Unique Goals and objectives. As the covid-19 epidemic affects our country, the goal of this study is to examine motivating elements that might influence employee performance while working from home. The respondents were chosen using standard random sampling procedures. The data was collected from 46 administrative personnel. The researcher studied several motivating elements and investigated how employee demographics such as age, gender, position, department, marital status, and housing situation may affect their degree of job satisfaction in this research study.
\end{abstract}

Keywords: employee motivation, motivational factors, work from home

\section{Introduction}

With the rise of the covid19 pandemic, there are certain things we have to accept as the new normal. Working from home for instance, before the pandemic, most employees want to be able to work from home to avoid the noise of the workplace.

As covid19 hit the world most of the companies struggled due to the impact of the virus. They are forced to let their employees work from home for the safety of everyone. In Singapore, safety management measures are implemented by the government; it declares that work from home is the default working base for the time being. Due to the increasing number of daily cases, working from home has been implemented for almost 2 years. And from time to time the government loosens up the restriction allowing the company to return their employee from work from home, to work to office only for the essential matter or to $50 \%$ of the employee workforce.

During this period of work from home, many of the companies' feedback on declining work progress and job performance of the employees. Some employees are not comfortable working at home, some are being a family person there are many distractions around. But some are quite like it, the work from home setting for them is easy to manage and they can work more actively and focus more on their work.

\section{Justification of the Proposed Research}

Retails Company established in Singapore in 2002, is a multinational company that consists of more than 700 employees up to date. There are 52 administrative employees' stores who are dealing with daily operations at the back end of the business.

Work from home brings a big impact to the retail industry's employees, making it difficult to communicate between back-end offices (administrative office) and the store operation, which is at the top of the employee's feedback. Working from home has many struggles not only for the company but also the employees; some difficulties are listed below; 
Work performance getting lower

Taking longer to respond to emails

Taking longer than usual to do the task

Not focus on the team engagement

High kids/Family disturbances

Too many calls and chats to communicate.

No time limit/ off to work

No Motivation

Computer malfunctions

And the list will continue depending on the task handling

The purpose of this study is how the company motivates the employee on their struggles while working from home. It might point out that the company and employees are not yet ready to adapt to the new environment and yet they have been oblique to do so.

\section{Statement of the Problem}

The research aims to assess employees' struggles and the company's desire to perform effectively even when they are working remotely, disregarding environmental hindrances that are encountered during the work timing.

3.1 In what Regards Do the Respondents' Demographic Differ?
a) Age
b) Sex
c) Work Status
d) Department
e) Legal Status
f) Living condition

3.2 Using the Two-Factor Theory of Motivation, What Are the Best Tactics for Motivating Workers Who Work from Home in Terms of the Following Factors

Hygiene factor
a) Salary Structure
b) Company Policies
c) Employee benefits
d) Working conditions
e) Employment Status
f) Peers Relationship
g) Job Security

Motivation factor

h) Work Recognition

i) Achievement

j) Growth and Development

k) Duties and Responsibility

1) Work Contribution

3.3 Is There a Significant Difference between the Respondents' Profiles and the Two Factors of Motivation Theory to Inspire the Employee from the Challenges He or She Faces When Working from Home?

3.4 What New Motivational Program may Be Proposed Based on the Findings? 


\section{Research Literature}

Dr. K. Selvasundaram, Suganya Dasaradhan (2020) 'Covid-2019 pandemic has imposed the sensitivity of 'Work from Home (WFH) into an authoritatively instructed, firmly forced law. Nowadays, Work from Home theory remains evolving from all sectors, from Information Technological zones to training areas. WFH concept is new to a majority of the employees, as the COVID 19 has forced almost all the employees of all the sectors to work from home for the first time. As the organizational employees are facing an innovative atmosphere, this paper effort to second out the involvement of the workers in employed from home when compared to operational in office. The study found that the employees willingly complete their work in work from home is depending upon the occurrence of their kids and family, a happy universe in-home, the discreet atmosphere at home-based, and also virtuous network connectivity. Most of the respondents are also of estimation that even if they are ready to work from home they do not like to work from home".

Julian Birkinshaw, Jordan Cohen, and Pawel Stach (2020) "Researchers studied knowledge workers in 2013 and again during the 2020 pandemic lockdown and found significant changes in how they are working. They learned that lockdown helps people focus on the tasks that matter. They spent $12 \%$ less time drawn into large meetings and 9\% more time interacting with customers and external partners. Lockdown also helped people take responsibility for their schedules. They did 50\% more activities through personal choice and half as many because someone else asked them to. Finally, during the lockdown, people viewed their work as more worthwhile. The number of tasks rated as tiresome dropped from $27 \%$ to $12 \%$, and the number we could readily offload to others dropped from $41 \%$ to $27 \%$."

Shep Hyken (2021) "Work from home has become business as usual. Not even a year ago, working remotely was an opportunity for just a small percentage of the workforce. Then along came the Covid-19 pandemic, and that caused an instantaneous change. Companies in traditional office spaces were forced to send their employees home to work remotely - and many of these employees will continue to work from home, long after the pandemic is over. The change was inevitable. While the pandemic imposed the WFH economy, it was going to happen anyway. Over time, businesses would have realized that technology enables this capability. Excluding factory jobs, restaurants, grocery stores, retail and other businesses that require people to be on location, many companies are finding the change is not as painful as they may have thought. While a 100\% WFH workforce may not be for every company, the number of companies that will adapt to a percentage of their workforce going remote will have a greater impact beyond the company, its employees, that and its customers."

\section{Theoretical Framework}

A behavioral scientist Frederick Herzberg (1959) proposed the Two-Factor Theory of Motivation also known as a motivator. These employment variables were divided into two groups by Herzberg:

\subsection{Hygiene Factors}

Hygiene Factors also known as dissatisfactions factors, those job elements that are required for motivation to continue at work. They are necessary to avert discontentment at the workplace. The employment environment is described by these characteristics. The hygiene aspects that represented the physiological demands that people sought and expected to be met are;

a. Salary structure- The wage or salary structure must be reasonable and acceptable. It must be competitive with those in the same industry.

b. Company Policies - help employers deal with accountability of employees, code of conduct and work Ethics as well as interactions with customers. The policies of the firm should be fair and transparent,

c. Employee benefits - In addition to their normal wages and salaries, employees may receive a variety of non-wage compensation such as bonuses, allowances, medical compensation, and other allowances that the company offers.

d. Working conditions - Clean and safe working conditions are necessary. Well-maintained work equipment is also needed.

e. Employment Status - employees must be are aware of their status within the organization.

f. Peers relationship - in the work environment, employees should maintain appropriate relationships with their fellow employees, superiors, and subordinates.

g. Job Security - Employees must be given job security by the company. 


\subsection{Motivational Factors}

Employees are motivated to achieve higher levels of performance as a result of these causes. These elements are known as satisfiers. These are aspects of the work that must be considered. These aspects are naturally rewarding to employees. The motivators represented the psychological requirements that were seen as a bonus. Among the motivating considerations are:

a. Work Recognition - encourage employees to repeat good performance by recognizing their behavior performance, effort, and accomplishment that help the organization to achieve its goals and values.

b. Achievement - engage employees in their job by inspiring them to achieve their goals.

c. Growth and Development - employees should be motivated by offering growth and development in their careers.

d. Duties and Responsibility - Employees must be held accountable for their jobs. Superior should assign authority over their work and give their employees respond with minimized control.

e. Work contribution- The assignment ought to be significant, fascinating, and trying for the worker to perform and to get inspired.

\section{Contribution of Research}

This research is appropriate in the current situation, where a pandemic is still experienced this study aims and the struggle for both employers and employees is still unstable due to the response of the environment.

The researcher intent to contribute to the company and the employees to recognize the experience's during work from home and the struggles accompanied by it based on the output of the research.

To Batangas State University and the future researcher and guide them to their studies.

Message to future successor this may serve as a reference to the future once the pandemic is gone and will help the researcher and the readers to evaluate the struggles of working from home during this period with both company and employer were not yet ready for the new working environment, hope in future work from home will be a part of a routine and the hindrances that been facing will be the positive outcome in time to come.

\section{Research Methodology}

The methodology of the research was divided into two stages; data collection and analysis of data.

The researcher used a questionnaire via Google form in gathering data and was sent to respective employee emails and they will answer the survey questions concerning the study.

The population size was 52 administrative employees and the 46 sample size was computed using the Raosoft calculator. The data collected from the questionnaire of the respondent was being tabulated, analyzed, and interpreted using the SPSD software. Inferential statistics were used in this study as it seeks to determine the significant difference between variables.

\section{Result and Discussion}

The study attempts to determine the struggle of employees and the company motivation to perform well even remotely, disregarding environmental hindrances that are encountered during the work timing.

\section{A. Respondent Demographics}

Table 1. Age Distribution of Respondents

\begin{tabular}{|c|c|c|}
\hline Bracket & Frequency & \% \\
\hline $21-25$ & 3 & 6.5 \\
$26-30$ & 21 & 45.7 \\
$31-35$ & 4 & 8.7 \\
$36-40$ & 8 & 17.4 \\
$41-45$ & 5 & 10.9 \\
$46-50$ & 4 & 8.7 \\
$51-55$ & 1 & 2.2 \\
\hline Total & $\mathbf{4 6}$ & $\mathbf{1 0 0}$ \\
\hline
\end{tabular}

Table 1 shows, the highest number of respondents at the age bracket 26-30 with a frequency of 21 respondents and a percentage of 45.7 percent. The least is the age bracket 51-55 with 1 respondent and 2.2 percent. 
Table 2. Sex Distribution of Respondents

\begin{tabular}{|c|c|c|}
\hline Sex & Frequency & \% \\
\hline Male & 5 & 10.9 \\
Female & 41 & 89.1 \\
\hline Total & $\mathbf{4 6}$ & $\mathbf{1 0 0}$ \\
\hline
\end{tabular}

Table 2 explain the assessment of the respondent's in terms of their sex, majority of the employees are a female population with taking 89.1 percent while the male population are 10.9 percent

Table 3. Legal Status Distribution of Respondents

\begin{tabular}{|c|c|c|}
\hline Legal status & $\begin{array}{c}\text { Frequenc } \\
\mathbf{y}\end{array}$ & $\mathbf{\%}$ \\
\hline Married & 21 & 45.7 \\
Single & 24 & 52.2 \\
Prefer not to say & 1 & 2.2 \\
\hline Total & $\mathbf{4 6}$ & $\mathbf{1 0 0}$ \\
\hline
\end{tabular}

The tabulated data above illustrate the distribution of the respondent in terms of their marital status; 52.2 percent are single with a frequency of 24 and 45.7 percent are married with a total number of 21 employees while 2.2 percent preferred not to say their marital status.

Table 4. Work Status Distribution of Respondents

\begin{tabular}{|c|c|c|}
\hline Work status & Frequency & \% \\
\hline Full time & 45 & 97.8 \\
Part-Time & 1 & 2.2 \\
\hline Total & $\mathbf{4 6}$ & $\mathbf{1 0 0}$ \\
\hline
\end{tabular}

The tabulated data above demonstrate the distribution of the respondent in terms of their work status; states that 97.8 percent are full-time employees with a rate of recurrence are 45 employees and 2.2 percent equivalent to 1 Part-Time Employee.

Table 5. Department Distribution of Respondents

\begin{tabular}{|c|c|c|}
\hline Department & Frequency & \% \\
\hline Human Resources & 10 & 21.7 \\
Accounts & 7 & 15.2 \\
Overseas Support & 11 & 23.9 \\
Logistic & 5 & 10.9 \\
Marketing & 2 & 4.3 \\
Purchasing & 7 & 15.2 \\
IT & 4 & 8.7 \\
\hline Total & $\mathbf{4 6}$ & $\mathbf{1 0 0}$ \\
\hline
\end{tabular}

Using random technique selection of the respondent, it describes above table that the division of the respondents base on their department; 11 or 23.9 percent of the employee are from Overseas Support which is the highest respondent, 10 or 21.7 percent are from Human Resources were ranked as a second highest respondent employee while marketing is in lowest rank with 4.3 percent or 2 respondent.

Table 6. Living Condition Distribution of Respondents

\begin{tabular}{|c|c|c|}
\hline Living condition & Frequency & Percentage \\
\hline Living With family & 31 & 67.4 \\
Bed space /shared room & 14 & 32.6 \\
\hline Total & $\mathbf{4 6}$ & $\mathbf{1 0 0}$ \\
\hline \multicolumn{2}{|r}{}
\end{tabular}


The table consists of a distribution of respondents in terms of their living conditions. Most of the respondents were living with their family with 67.4 percent and the remaining were bed spacers with 32.6 percent.

\section{B. Assessment on Motivational Factors of Work from Home Employees}

\section{Hygiene Factor}

Table 7. Assessment on the Factors that Motivate the Employees during Work from Home Arrangement

\begin{tabular}{|c|c|c|}
\hline $\begin{array}{l}\text { Salary Structure } \\
\end{array}$ & Weighted Mean & Verbal Interpretation \\
\hline $\begin{array}{l}\text { The company provides a clear, appropriate and reasonable salary } \\
\text { scheme }\end{array}$ & 2.96 & Agree \\
\hline $\begin{array}{l}\text { The salary is competitive to the similar company providing similar } \\
\text { services }\end{array}$ & 2.89 & Agree \\
\hline $\begin{array}{l}\text { My pay level and raises were fair to my job performance and } \\
\text { responsibilities }\end{array}$ & 2.89 & Agree \\
\hline COMPOSITE MEAN & 2.91 & Agree \\
\hline
\end{tabular}

According to the above-mentioned data, the majority of respondents approve of the company's salary structure; the weighted mean is 2.91 , which corresponds to the agreed responses. The highest weighted means (2.96), and verbal interpretation is equivalent to agree, are the salary structures that the organization gives a clear, appropriate, and reasonable salary scheme.

Table 8. Assessment on the Factors that Motivate the Employees during Work from Home Arrangement

\begin{tabular}{|c|c|c|}
\hline Company Policies and Administrative Policies & Weighted Mean & Verbal Interpretation \\
\hline I have a clear understanding of the company policies & 3.20 & Agree \\
\hline The policies display fairness and equality at all levels of the company & 3.02 & Agree \\
\hline My job description accurately reflects on what I am asked to do & 3.0 & Agree \\
\hline COMPOSITE MEAN & 3.07 & Agree \\
\hline
\end{tabular}

As illustrated above, company policies and administrative policies during work from home arrangements are agreeable which results in a 3.07 average. Having a clear understanding of the company policies weighted the highest mean of 3.20 while the lowest agreeable mean is Job description accurately reflects on what I am asked to do which are 3.0.

Table 9. Assessment on the Factors that Motivate the Employees during Work from Home Arrangement

\begin{tabular}{|l|c|c|}
\hline \multicolumn{1}{|c|}{ Fringe Benefits } & Weighted mean & $\begin{array}{c}\text { Verbal } \\
\text { Interpretation }\end{array}$ \\
\hline $\begin{array}{l}\text { The benefits are competitive to similar organizations providing similar } \\
\text { services }\end{array}$ & 2.87 & Agree \\
\hline $\begin{array}{l}\text { Allowances, medical reimbursements, and insurances are provided on } \\
\text { time }\end{array}$ & 2.85 & Agree \\
\hline COMPOSITE MEAN & $\mathbf{2 . 8 6}$ & Agree \\
\hline
\end{tabular}

The company's fringe benefits, as assessed and tabulated above, average $\mathbf{2 . 8 6}$ or agree as verbal interpretation; the benefits are competitive to similar organizations providing similar services, resulting in 2.87 or equivalent to agree where allowances, medical reimbursement, and insurances are provided on time, resulting in 2.85 equivalent to agreeing as verbal interpretation.

Table 10. Assessment on the Factors that Motivate the Employees during Work from Home Arrangement

\begin{tabular}{|c|c|c|}
\hline $\begin{array}{c}\text { Physical Working Condition } \\
\end{array}$ & Weighted Mean & Verbal Interpretation \\
\hline Physical working condition is safe, clean, and hygienic & 3.17 & Agree \\
\hline $\begin{array}{l}\text { The buildings, grounds, This study aims and layout of the facilities are } \\
\text { adequate for me to perform my duties }\end{array}$ & 3.13 & Agree \\
\hline $\begin{array}{l}\text { The company provides all the equipment, supplies, and resources } \\
\text { necessary to perform my work duties }\end{array}$ & 3.04 & Agree \\
\hline $\begin{array}{l}\text { Work from home schedule does not decrease the level of my } \\
\text { production }\end{array}$ & 2.89 & Agree \\
\hline COMPOSITE MEAN & 3.06 & Agree \\
\hline
\end{tabular}


the above table 10 assessed and tabulated enable to know the factors that motivate the employees during work from home arrangement, the respondent Agree with a weighted mean of $\mathbf{3 . 0 6}$ on Physical working conditions; where Physical working condition is safe, clean, and hygienic are assessed and measured at an average of 3.17 while Work from home schedule does not decrease in the level of my production, are resulting in the lowest rank 2.89 in the analysis.

Table 11. Assessment on the Factors that Motivate the Employees during Work from Home Arrangement

\begin{tabular}{|c|c|c|}
\hline Status & Weighted Mean & Verbal Interpretation \\
\hline $\begin{array}{l}\text { I am satisfied with how my supervisor has worked with me to identify } \\
\text { strengths and development areas }\end{array}$ & 3.11 & Agree \\
\hline I am satisfied with the level of supervision I received & 3.04 & Agree \\
\hline COMPOSITE MEAN & 3.08 & Agree \\
\hline
\end{tabular}

the assessed data interpret on the above Table 11 shows that the working status in the company during work arrangement are agreeable with an average of 3.08; where 3.11 are the highest pertaining for, I am satisfied with how my supervisor has worked with me to identify strengths and development area while I am satisfied with the level of supervision I received are analyzed as 3.04 weighted mean and equivalent do agree.

Table 12. Assessment on the Factors that Motivate the Employees during Work from Home Arrangement

\begin{tabular}{|l|c|c|}
\hline \multicolumn{1}{|c|}{ Interpersonal Relations } & $\begin{array}{c}\text { Weighted } \\
\text { Mean }\end{array}$ & $\begin{array}{c}\text { Verbal } \\
\text { Interpretation }\end{array}$ \\
\hline $\begin{array}{l}\text { The organizational lines of communication } \\
\text { flow easily }\end{array}$ & 2.91 & Agree \\
\hline $\begin{array}{l}\text { I feel I can easily communicate with } \\
\text { employees from all levels of the company }\end{array}$ & 2.98 & Agree \\
\hline $\begin{array}{l}\text { I believe employees are treated with the } \\
\text { utmost respect by other employees }\end{array}$ & 3.0 & Agree \\
\hline COMPOSITE MEAN & $\mathbf{2 . 9 6}$ & Agree \\
\hline
\end{tabular}

As shown in the table above the interpersonal relations assessment on the factors that motivate the employees during work from home arrangement is rated as 2.96 or Agree as verbal interpretation; the highest rating is I believe employees are treated with the utmost respect by other employees which we rated 3.0 or agree and The organizational lines of communication flow easily is rated as 2.91 or agree.

Table 13. Assessment on the Factors that Motivate the Employees during Work from Home Arrangement

\begin{tabular}{|l|c|c|}
\hline \multicolumn{1}{|c|}{ Job Security } & Weighted Mean & Verbal Interpretation \\
\hline $\begin{array}{l}\text { The company is practicing unbiased rules about employment } \\
\text { regularization and termination }\end{array}$ & 2.96 & Agree \\
\hline $\begin{array}{l}\text { Performance evaluation is being given for improvements of the } \\
\text { employees }\end{array}$ & 2.98 & Agree \\
\hline $\begin{array}{l}\text { I am satisfied with how the company addresses internal and external } \\
\text { issues that may affect employee retention }\end{array}$ & 2.89 & Agree \\
\hline COMPOSITE MEAN & $\mathbf{2 . 9 4}$ & Agree \\
\hline
\end{tabular}

As shown and rated in table 13, respondents agree on job security, which is calculated as 2.94 as statistically agreeable at the same time respondents agree on Performance evaluation are being given for improvements of the employees which taking the highest rate of 2.98 in the evaluation and I am satisfied with how the company addresses internal and external issues that may affect employee retention, which is evaluated as 2.89

\section{Motivational Factor}

Table 14. Assessment on the Factors that Motivate the Employees during Work from Home Arrangement

\begin{tabular}{|c|c|c|}
\hline Recognition & Weighted Mean & Verbal Interpretation \\
\hline I believe that I received the recognition I deserve for my contribution & 3.02 & Agree \\
\hline The management encourages and recognizes new ideas & 3.04 & Agree \\
\hline Employees are rewarded based on ability and accomplishments & 2.96 & Agree \\
\hline COMPOSITE MEAN & 3.01 & Agree \\
\hline
\end{tabular}


in review at the above table 14, Recognition in motivation factor that Motivates the Employees during Work from Home Arrangement are evaluated 3.01 or agree based on means of statistics, employee recognition evaluated by the respondent and appraised where I believe that I received the recognition I deserve for my contribution resulted in 3.02 or agree equivalent on verbal interpretation in statistic and Employees are rewarded based on ability and accomplishments is rated as 2.96 or agree statistically.

Table 15. Assessment on the Factors that Motivate the Employees during Work from Home Arrangement

\begin{tabular}{|l|c|c|}
\hline \multicolumn{1}{|c|}{ Sense of Achievement } & Weighted Mean & Verbal Interpretation \\
\hline $\begin{array}{l}\text { The management makes changes and adjustments based on my } \\
\text { suggestions and feedback }\end{array}$ & 2.91 & Agree \\
\hline I am satisfied with how my skill is being utilized by the company & 2.96 & Agree \\
\hline COMPOSITE MEAN & $\mathbf{2 . 9 3}$ & Agree \\
\hline
\end{tabular}

The sense of achievement is weighted mean 2.93 or agree as interpreted statistically are evaluated by the respondents based on the motivation factor of the employee during work from home arrangement as shown in the above table 15. The management makes changes and adjustments based on my suggestions and feedback is a score of 2.91 or agree and I am satisfied with how my skill is being utilized by the company is rated 2.96 or agree.

Table 16. Assessment on the Factors that Motivate the Employees during Work from Home Arrangement

\begin{tabular}{|c|c|c|}
\hline $\begin{array}{c}\text { Growth and Promotional Opportunities } \\
\end{array}$ & Weighted Mean & Verbal Interpretation \\
\hline I am provided opportunities for job growth and development & 3.0 & Agree \\
\hline I am provided with all training necessary for me to perform my job & 2.91 & Agree \\
\hline I am satisfied with my chances for promotion & 2.87 & Agree \\
\hline COMPOSITE MEAN & 2.93 & Agree \\
\hline
\end{tabular}

The tabulated data above clarify the Growth and Promotional Opportunities which are evaluated by the employee is 2.93 or agreeable, among the survey questions I am provided with opportunities for job growth and development which rank highest of 3.0 while I am satisfied with my chances for promotion which rank lowest of 2.87 or agreeable.

Table 17. Assessment on the Factors that Motivate the Employees during Work from Home Arrangement

\begin{tabular}{|c|c|c|}
\hline Responsibility & Weighted Mean & Verbal Interpretation \\
\hline Employees are accountable for their judgment & 3.10 & Agree \\
\hline The level of responsibility is well-defined to every single employee & 3.04 & Agree \\
\hline Employees perceived that they have ownership of their work & 3.02 & Agree \\
\hline COMPOSITE MEAN & 3.05 & Agree \\
\hline
\end{tabular}

The weighted averages of responsibility in motivating variables that ended in 3.05 or agree are shown in Table 17. Employee duties are described as follows: Employees are accountable for their judgment is 3.10 or agree, while Employees think that they have ownership of their work is 3.02, which is the lowest-ranked.

Table 18. Assessment on the Factors that Motivate the Employees during Work from Home Arrangement

\begin{tabular}{|c|c|c|}
\hline Meaningfulness of the work & Weighted Mean & Verbal Interpretation \\
\hline I always want to give my best whenever I'm at work & 3.24 & Agree \\
\hline I am proud to be part of the company & 3.09 & Agree \\
\hline I am willing to spend the rest of my career in this organization & 2.87 & Agree \\
\hline COMPOSITE MEAN & 3.07 & Agree \\
\hline
\end{tabular}

Meaningfulness of the work are reviewed by the respondent employees and graded 3.07 or agree, during work from home arrangement employee evaluated the highest rank which is 3.24 or agreeable in the statement always want to give my best whenever I'm at work while the lowest rank score 2.87 or agree on the statement I am willing to spend the rest of my career in this organization 


\section{Significant Difference Between Profile of the Respondents and the Two-factor Motivation Theory}

Table 19. Significant Difference between the Respondent's Age and Factors that Motivates them while Working from Home

\begin{tabular}{|c|c|c|c|c|}
\hline Variables & p-value & Computed value & Decision on Ho & Verbal Interpretation \\
\hline \multicolumn{5}{|c|}{ HYGIENE FACTOR } \\
\hline Salary Structure & .217 & 22.349 & Failed to Reject & Not Significant \\
\hline Company Policies & .908 & 6.162 & Failed to Reject & Not Significant \\
\hline Fringe & .710 & 14.288 & Failed to Reject & Not Significant \\
\hline Physical & .102 & 18.463 & Failed to Reject & Not Significant \\
\hline Status & .064 & 20.149 & Failed to Reject & Not Significant \\
\hline Interpersonal & .169 & 23.601 & Failed to Reject & Not Significant \\
\hline Job security & .000 & 54.483 & Reject & Not Significant \\
\hline \multicolumn{7}{|c|}{ MOTIVATIONAL FACTOR } \\
\hline Recognition & .239 & 15.046 & Failed to Reject & Not Significant \\
\hline Sense & .059 & 20.473 & Failed to Reject & Not Significant \\
\hline Growth & .341 & 19.854 & Failed to Reject & Significant \\
\hline Responsibility & .036 & 22.172 & Reject & Not Significant \\
\hline Meaningfulness & .472 & 11.682 & Failed to Reject &
\end{tabular}

The results of the significant difference in respondent age and the two-factor motivation hypothesis are presented in the table above. The $\mathrm{p}=$ value of age when it comes to job security is at .000 and responsibility is at .036 was found to be significant as factors that motivate employees while working from home. On the other hand, other factors were found to be not significant with the respondent's two-factor age as motivation for work from home employees.

Table 20. Significant Difference between the Respondent's Sex and Factors that Motivates them while Working from Home

\begin{tabular}{|l|c|c|c|c|}
\hline \multicolumn{1}{|c|}{ Variables } & p-values & $\begin{array}{c}\text { Computed } \\
\text { values }\end{array}$ & Decision on Ho & $\begin{array}{c}\text { Verbal } \\
\text { Interpretation }\end{array}$ \\
\hline \multicolumn{5}{|c|}{ HYGIENE FACTOR } \\
\hline Salary Structure & .773 & 1.115 & Failed to Reject & Not Significant \\
\hline $\begin{array}{l}\text { Company } \\
\text { Policies }\end{array}$ & .756 & .560 & Failed to Reject & Not Significant \\
\hline Fringe & .519 & 2.265 & Failed to Reject & Not Significant \\
\hline Physical & .014 & 8.497 & Reject & Significant \\
\hline Status & .705 & .698 & Failed to Reject & Not Significant \\
\hline Interpersonal & .809 & .968 & Failed to Reject & Not Significant \\
\hline Job security & .726 & 1.312 & Failed to Reject & Not Significant \\
\hline \multicolumn{7}{|c|}{ MOTIVATIONAL FACTOR } \\
\hline Recognition & .661 & .829 & Failed to Reject & Not Significant \\
\hline Sense & .556 & 1.173 & Failed to Reject & Not Significant \\
\hline Growth & .941 & .398 & Failed to Reject & Not Significant \\
\hline Responsibility & .530 & 1.272 & Failed to Reject & Not Significant \\
\hline Meaningfulness & .005 & 10.774 & Reject & Significant \\
\hline
\end{tabular}

The table above presents the result of the significant difference between respondents' sex and the two-factor motivation theory. The $\mathrm{p}=\mathrm{value}$ of $\mathrm{sex}$ when it comes to physical working condition $(\mathrm{p}=.014)$ and meaningfulness of work $(\mathrm{p}=.005)$ was found to be significant factors that motivate employees while working from home. On the other hand, other factors were found to be not significant with respondent's sex as motivation for work from home employees. 
Table 21. Significant Difference Between the Respondent's Work Status and Factors that Motivates them while Working from Home

\begin{tabular}{|l|c|c|c|c|}
\hline \multicolumn{7}{|c|}{ Variables } & p-values & $\begin{array}{c}\text { Computed } \\
\text { values }\end{array}$ & Decision on Ho & $\begin{array}{c}\text { Verbal } \\
\text { Interpretation }\end{array}$ \\
\hline \multicolumn{5}{|c|}{ HYGIENE FACTOR } \\
\hline Salary Structure & .078 & 6.815 & Failed to Reject & Not Significant \\
\hline Company policies & .088 & 4.856 & Failed to Reject & Not Significant \\
\hline Fringe & .183 & 4.856 & Failed to Reject & Not Significant \\
\hline Physical & .235 & 2.896 & Failed to Reject & Not Significant \\
\hline Status & .122 & 4.202 & Failed to Reject & Not Significant \\
\hline Interpersonal & .948 & .361 & Failed to Reject & Not Significant \\
\hline Job security & .948 & .361 & Failed to Reject & Not Significant \\
\hline \multicolumn{7}{|c|}{ MOTIVATIONAL FACTOR } \\
\hline Recognition & .033 & 6.815 & Reject & Significant \\
\hline Sense & .852 & .321 & Failed to Reject & Not Significant \\
\hline Growth & .078 & 6.815 & Failed to Reject & Not Significant \\
\hline Responsibility & .868 & .284 & Failed to Reject & Not Significant \\
\hline Meaningfulness & .058 & 5.695 & Failed to Reject & Not Significant \\
\hline
\end{tabular}

The significant difference between the respondent's working status and the two-factor motivation theory is seen in the table above. The $\mathrm{p}=$ value of work status when it comes to recognition is computed at .033 was found to be significant as a factor that motivates employees while working from home. On the other hand, other factors were found to be not significant with respondents' working status as motivation for work from home employees.

Table 22. Significant Difference between the Respondent's Department and Factors that Motivates them while Working from Home

\begin{tabular}{|l|l|l|l|l|}
\hline \multicolumn{6}{|c|}{ Variables } & \multicolumn{1}{|c|}{ p-values } & $\begin{array}{c}\text { Computed } \\
\text { values }\end{array}$ & \multicolumn{1}{|c|}{ Decision on Ho } & \multicolumn{1}{c|}{$\begin{array}{c}\text { Verbal } \\
\text { Interpretation }\end{array}$} \\
\hline \multicolumn{5}{|c|}{ HYGIENE FACTOR } \\
\hline Salary Structure & .034 & 30.339 & Reject & Significant \\
\hline Company policies & .000 & 36.150 & Reject & Significant \\
\hline Fringe & .033 & 30.439 & Reject & Significant \\
\hline Physical & .222 & 15.367 & Failed to Reject & Not Significant \\
\hline Status & .08 & 19.358 & Failed to Reject & Not Significant \\
\hline Interpersonal & .011 & 34.592 & Reject & Significant \\
\hline Job security & .443 & 18.194 & Failed to Reject & Not Significant \\
\hline \multicolumn{7}{|l|}{ MOTIVATIONAL FACTOR } & Significant \\
\hline Recognition & .047 & 21.249 & Reject & Not Significant \\
\hline Sense & .276 & 14.393 & Failed to Reject & Not Significant \\
\hline Growth & .269 & 21.210 & Failed to Reject & Not Significant \\
\hline Responsibility & .425 & 12.256 & Failed to Reject & Significant \\
\hline Meaningfulness & .035 & 22.230 & Reject &
\end{tabular}

Above table 22 displays the result of the significant difference between employees department and the two-factor motivation theory. The $p=$ value of respondent's department when it comes to salary structure $(p=.034)$, company policies $(\mathrm{p}=.000)$, fringe benefits $(\mathrm{p}=.033)$, interpersonal relation $(\mathrm{p}=.011)$, recognition $(\mathrm{p}=.047)$, meaningfulness $(\mathrm{p}=.035)$ was found to be significant as factors that motivate employees while working from home. On the other hand, other factors were found to be not significant with the respondent's department as motivation for work from home employees. 
Table 23. Significant Difference Between the Respondent's Marital Status and Factors that Motivates them while Working from Home

\begin{tabular}{|c|c|c|c|c|}
\hline Variables & P-value & $\begin{array}{c}\text { Computed } \\
\text { value }\end{array}$ & Decision on Ho & $\begin{array}{c}\text { Verbal } \\
\text { Interpretation }\end{array}$ \\
\hline \multicolumn{5}{|c|}{ HYGIENE FACTOR } \\
\hline Salary Structure & .682 & 3.958 & Failed to Reject & Not Significant \\
\hline Company policies & .245 & 5.443 & Failed to Reject & Not Significant \\
\hline Fringe & .000 & 51.814 & Reject & Significant \\
\hline Physical & .949 & .716 & Failed to Reject & Not Significant \\
\hline Status & .29 & 4.974 & Failed to Reject & Not Significant \\
\hline Interpersonal & .657 & 4.147 & Failed to Reject & Not Significant \\
\hline Job security & .082 & 11.210 & Failed to Reject & Not Significant \\
\hline \multicolumn{7}{|c|}{ MOTIVATIONAL FACTOR } \\
\hline Recognition & .890 & 1.127 & Failed to Reject & Not Significant \\
\hline Sense & .743 & 1.960 & Failed to Reject & Not Significant \\
\hline Growth & .907 & 2.137 & Failed to Reject & Not Significant \\
\hline Responsibility & .584 & 2.837 & Failed to Reject & Not Significant \\
\hline Meaningfulness & .778 & 1.769 & Failed to Reject & Not Significant \\
\hline
\end{tabular}

Table 23 above demonstrates the result of the significant difference between the respondent's marital status and the two-factor motivation theory. The $\mathrm{p}=$ value of marital status when it comes to fringe benefit is computed at .000 was found to be significant as a factor that motivates employees while working from home. On the other hand, other factors were found to be not significant with respondents' marital status as motivation for work from home employees.

Table 24. Significant Difference between the Respondent's Living Condition and Factors that Motivates them while Working from Home

\begin{tabular}{|c|c|c|c|c|}
\hline Variables & P-value & $\begin{array}{c}\text { Computed } \\
\text { values }\end{array}$ & Decision on Ho & $\begin{array}{c}\text { Verbal } \\
\text { Interpretation }\end{array}$ \\
\hline \multicolumn{5}{|c|}{ HYGIENE FACTOR } \\
\hline Salary Structure & .920 & .495 & Failed to Reject & Not Significant \\
\hline Company policies & .864 & .291 & Failed to Reject & Not Significant \\
\hline Fringe & .24 & 4.202 & Failed to Reject & Not Significant \\
\hline Physical & .303 & 2.391 & Failed to Reject & Not Significant \\
\hline Status & .618 & .962 & Failed to Reject & Not Significant \\
\hline Interpersonal & .894 & .611 & Failed to Reject & Not Significant \\
\hline Job security &. .085 & 6.633 & Failed to Reject & Not Significant \\
\hline \multicolumn{7}{|c|}{ MOTIVATIONAL FACTOR } \\
\hline Recognition & .546 & 1.210 & Failed to Reject & Not Significant \\
\hline Sense & .546 & 1.160 & Failed to Reject & Not Significant \\
\hline Growth & .382 & 3.063 & Failed to Reject & Not Significant \\
\hline Responsibility & .606 & 1.00 & Failed to Reject & Not Significant \\
\hline Meaningfulness & .408 & 1.795 & Failed to Reject & Not Significant \\
\hline
\end{tabular}

As tabulated above it shows and evaluates the significant difference between respondent's living conditions and the two-factor motivation theory. The result shows that the respondent's living condition has no significant difference between the two-factor motivation theories for employees working from home.

\section{Conclusions}

The following conclusions were formed based on the findings:

1. As corresponds the respondents are within the age bracket of 26-30, single, female, full-time employees and living with their family

2. As a result of the analysis, it concludes that Employees Agreed on the motivational factor that the company is offering based on the survey question guided by Hygiene Factor and Motivational factor. It also concludes that based on the statistical analysis the profile of the respondents is not significant or not important to the employee.

3. Demographic characteristics have a substantial impact on an employee's level of motivation. It was observed that age has a significant difference in the job security of an employee. Also, sex provides a 
significant difference between the meaningfulness of their work. Moreover, there is a significant difference between work status and recognition. Furthermore, the department has significant differences with salary structure, company policies, fringe benefits, interpersonal relations, recognition, and meaningfulness of the work. Additionally, there's a significant difference between marital status and fringe benefits. On the other hand, living conditions do not provide a significant difference with any of the motivational factors.

\section{Recommendations}

The researcher proposes a new motivational procedure to improve employee morale:

1. Management may take into account to consider improving the current motivational factors or add additional inspiration for the employee.

2. Management is encouraged to implement a Performance Management system (PMS) to closely monitor individual performance.

3. Human Resource may have a training course for each Department Team that needs to motivate more employees and work progressively.

4. Coaching programs are also recommended for good working conditions for employee engagement, updates for the management and company objective shall be sequentially updated.

5. Future researchers may modify this study by correlating other factors affecting employee motivation during work from home

\section{References}

Andy, N. Association of Professional Trainers, Singapore (2006-2021). Top 10 factors that motivate employees. Retrieved from

https://www.aptsg.com/index.php/articles-2/15-for-employers-hr-training-dept/36-top-10-factors-that-motiv ate-employees

Frederick, H. (1959). Herzberg's Two-Factor Theory of Motivation. Retrieved from https://www.managementstudyguide.com/herzbergs-theory-motivation.htm

Gusti, A. N. P., \& Putu, S. P. (2020). The Role of Job Satisfaction Mediation on The Relation of Intrinsic and Extrinsic Motivations toward Employee's Performance of Pt Pegadaian (Persero) Branch Offices In Denpasar. Retrieved from https://iosrjournals.org/iosr-jbm/papers/Vol22-issue5/Series-6/A2205060112.pdf

Julian, B., Jordan, C., \& Pawel, S. (2020). Research: Knowledge Workers Are More Productive from Home. Retrieved from https://hbr.org/2020/08/research-knowledge-workers-are-more-productive-from-home

Richard, K., \& Carlene, C. (2013). Management (12nd ed.).

Selvasundaram, K., \& Suganya, D. (2020). A Comparative Study On Work From Home During Covid 2019: Employees Perception And Experiences. Retrieved from https://ejmcm.com/article_4695_52b6119f4aff7bc4614b70e7448feccf.pdf

Shep, H. (2021). The Impact Of The Remote Workforce. Retrieved from https://www.forbes.com/sites/shephyken/2021/02/28/the-impact-of-the-virtual-work-from-home-workforce/ $? \mathrm{sh}=2535 \mathrm{eb} 302873$

Tim, B. (2021). Work From Home Is The New Normal For Workers Around The World. Retrieved from https://www.forbes.com/sites/timbajarin/2021/04/29/work-from-home-is-the-new-normal-for-workers-arou nd-the-world/?sh=10f972767c20

\section{Copyrights}

Copyright for this article is retained by the author(s), with first publication rights granted to the journal.

This is an open-access article distributed under the terms and conditions of the Creative Commons Attribution license (http://creativecommons.org/licenses/by/4.0/). 